\title{
Acalyptris amazonensis sp. nov.: documentation of another leaf-mining species supplementing the unique but disputable $A$. latipennata group (Lepidoptera: Nepticulidae)
}

\author{
Jonas R. Stonis ${ }^{1,2^{*}}$, \\ Arūnas Diškus ${ }^{1}$ \\ ${ }^{1}$ Vytautas Magnus University \\ and Baltic-American \\ Biotaxonomy Institute, \\ Studentu St. 39, Vilnius 08106, \\ Lithuania \\ ${ }^{2}$ Institute of Ecology, \\ Nature Research Centre, \\ Akademijos St. 2, \\ Vilnius 08412, Lithuania
}

\begin{abstract}
We describe one new species (Acalyptris amazonensis sp. nov.) from the Amazonian rainforest of Ecuador and provide the first photographic documentation of two other related species also occurring in Ecuador (A. onorei Puplesis \& Diškus and A. ecuadoriana Puplesis \& Diškus). We briefly discuss diagnostic characters of the A. latipennata species group, which has an outstanding but disputable position within the genus Acalyptris Meyrick.
\end{abstract}

Keywords: Acalyptris amazonensis, Acalyptris Meyrick, leaf mines, Nepticulidae, new species, latipennata group

\section{INTRODUCTION}

The history of documentation of the Nepticulidae fauna of Ecuador counts only the past 16 years. The first species recorded from this equatorial South American country with outstanding biodiversity were described in a paper by Puplesis and Robinson (Puplesis et al., 2002a) that enriched science with sixteen new species from the western Amazonian rainforest and the Andes of Ecuador. This study was followed by another paper adding a couple more species to the fauna of Ecuador: one species previously known from the USA (Florida), Belize, and the Caribbean, and one species previously known from Belize (Puplesis et al., 2002b). Recently a series of taxonomic publications on

\footnotetext{
*Corresponding author. Email: stonis.biotaxonomy@gmail.com
}

Nepticulidae also covering Ecuador was published, notably, Remeikis et al., 2014; Stonis et al., 2014, 2015, 2016a, 2016c, 2016b, 2016d, 2017a, 2017c, 2017d, 2018a, 2018b.

Nepticulidae (or pygmy moths) is a rather peculiar group of monotrysian Lepidoptera. The family comprises the world's smallest moths, the larvae of which are leaf miners during all stages of their development. Documentation of these tiny but ecologically and economically important insects is often hampered by the lack of qualified specialists and also, possibly, by the minute size of the adults of Nepticulidae. They are usually neglected on a lighttrap screen, absent or rare in many scientific collections, and, when collected, the dissection of these "pygmies" requires great skills and experience.

Thanks to Professor Onore Giovanni, the first field collecting, specifically targeted at the 
Ecuadorian Oriente (Amazon) region, was conducted in 1999 and in the following years. Later, Nepticulidae were discovered practically in all major terrestrial habitats of Ecuador, sometimes being very prolific, particularly in the Andes. Despite the ongoing effort and the continuously rising number of registered species, the currently known number - about 30 species - is very far from an expected number of actually occurring species in this exceptional country.

Here, we are continuing to document the Nepticulidae fauna of Ecuador and describe one more species, Acalyptris amazonensis sp. nov., from the western Amazonian rainforest. This particular species belongs to the unique informal group among Nepticulidae, the Acalyptris latipennata group. The group was already known from the Amazonian rainforest due to two other earlier described Acalyptris species. The discovery of $A$. amazonensis is important. It sheds more light on taxonomic and morphological diversity of the latipennata group, a unit whose taxonomic placement in Acalyptris is still debatable. We also provide the first photographic documentation of previously described members of the A. latipennata group from Ecuador, and for the first time report on a host plant for the A. latipennata group with previously fully unknown biology.

\section{MATERIALS AND METHODS}

Description of the new species and documentation of the previously described species are based on the material deposited in the collection of the Natural History Museum, London, United Kingdom, which was collected in Ecuador by J. R. Stonis, formerly Rimantas Puplesis, and S. R. Hill thanks to research projects conducted together with Ecuadorian scientific partners, including the initial project of 1999 together with Professor Giovanni Onore, a former professor at the Pontifical Catholic University of Ecuador, Quito, Ecuador.

Collecting methods and protocols for species identification and description are outlined in Puplesis (1994); Puplesis, Robinson (2000); and Puplesis, Diškus (2003). After maceration of the abdomen in $10 \% \mathrm{KOH}$ and subsequent cleaning, male genital capsules were removed from the abdomen and mounted ventral side uppermost. The phallus was removed and mounted in Euparal separately, but on the same genitalia slide. Abdominal pelts and female genitalia were stained with Chlorazol Black (Direct Black 38/ Azo Black) (for a detailed description of the method see Stonis et al., 2014).

Permanent slides were photographed and studied using a Leica DM2500 microscope and Leica DFC420 digital camera. The descriptive terminology of morphological structures follows Puplesis, Robinson (2000), except for the term "aedeagus", which is here referred to as "phallus", and the term "cilia", which is here referred to as "fringe".

Institutional abbreviation used in the text: BMNH - The Natural History Museum, London, United Kingdom; PUCE - Pontificia Universidad Católica del Ecuador, Quito, Ecuador.

\section{DESCRIPTION OF ACALYPTRIS AMA- ZONENSIS STONIS \& DIŠKUS, SP. NOV.}

(Figs. 1-3, 6-9, 14, 27-35)

Type material. Holotype: $\hat{\partial}$, ECUADOR: Napo Province, Misahualli, $17 \mathrm{~km}$ SE of Tena, $1^{\circ} 01^{\prime} 32^{\prime \prime} \mathrm{S}, 77^{\circ} 40^{\prime} 16^{\prime \prime} \mathrm{W}$, elevation $410 \mathrm{~m}$, mining larvae on Psychotria L. (Rubiaceae), 28.i.2001, fieldwork card nos. 4743, 4723, R. Puplesis \& S. Hill, genitalia slide no. AD352 (BMNH).

Diagnosis. Acalyptris amazonensis sp. nov. belongs to the A. latipennata species group and it most resembles two other species in this group also occurring in the western Amazonian rainforest of Ecuador: A. onorei Puplesis \& Diškus and A. ecuadoriana Puplesis \& Diškus. However, by the external characters such as the forewing pattern and the male genitalia, the new species A. amazonensis sp. nov. can be easily distinguished from these species, also from all the remaining Acalyptris.

A. amazonensis sp. nov. differs from Acalyptris onorei Puplesis \& Diškus, 2002 in the very glossy forewing with large, distinct, silvery shiny, subapical patches, and in the absence of androconia on hindwing; in the male genitalia, A. amazonensis sp. nov. differs in the significantly reduced, 


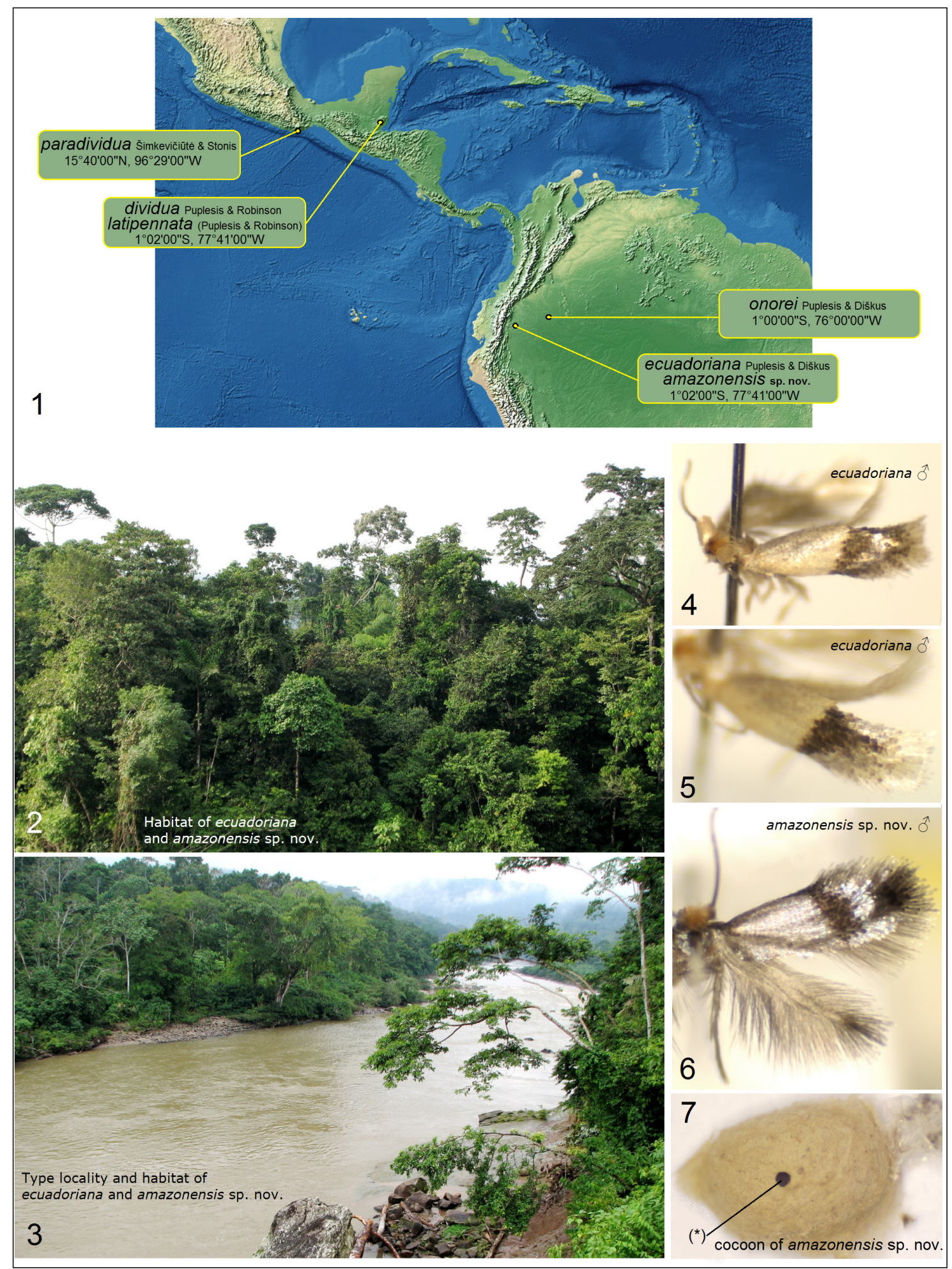

Figs. 1-7. Species of the Acalyptris latipennata group. 1 - distribution map; 2, 3 - type locality and habitat of A. ecuadoriana Puplesis \& Diškus and A. amazonensis Stonis \& Diškus, sp. nov., western Amazonian rainforest, $1^{\circ} 01^{\prime} 32^{\prime \prime}$, $77^{\circ} 40^{\prime} 16^{\prime \prime} \mathrm{W}$, elevation $410 \mathrm{~m}$, Misahualli, $17 \mathrm{~km}$ SE of Tena, Napo Province, Ecuador; 4, 5 - A. ecuadoriana, male adult, paratype (BMNH); 6 - A. amazonensis, male adult, holotype (BMNH); 7 - same, cocoon.

* artefact; the hole of the minutien pin. 


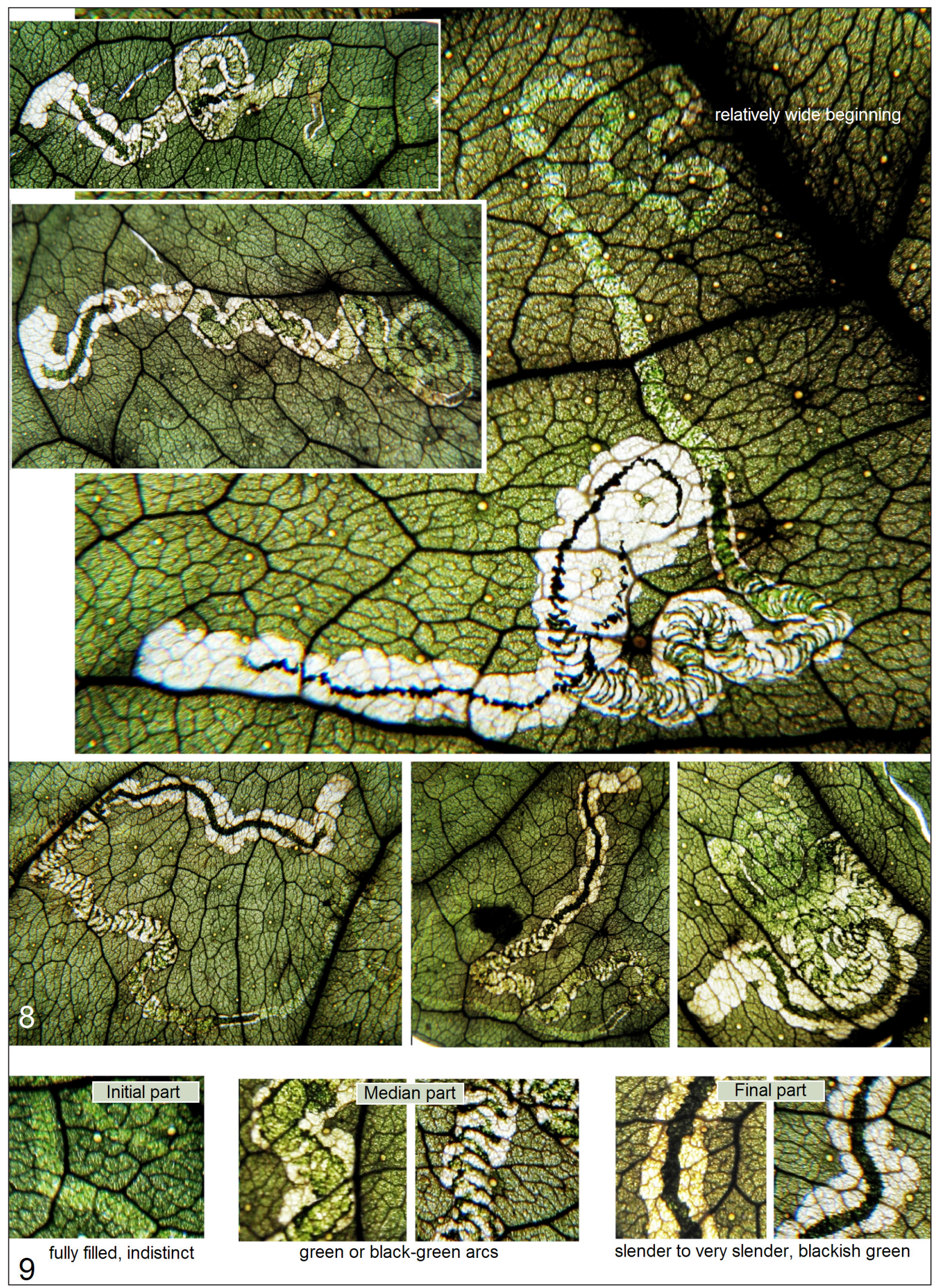

Figs. 8, 9. Documentation of leaf mines of Acalyptris amazonensis Stonis \& Diškus, sp. nov., collected in western Amazonian rainforest, $1^{\circ} 01^{\prime} 32^{\prime \prime}$, $77^{\circ} 40^{\prime} 16^{\prime \prime} \mathrm{W}$, elevation $410 \mathrm{~m}$, Misahualli, $17 \mathrm{~km}$ SE of Tena, Napo Province, Ecuador. 8 - general morphology; 9 - frass deposition 
slender arms of gnathos (stout in A. onorei), narrow posterior lobes of vinculum (wide in $A$. onorei, see Fig. 19), straight sublateral proceeses of valva (bent outwardly in A. onorei), presence of basal and median thickenings of valva, wider gap between valval processes, and the wide phallus in its apical half.

From Acalyptris ecuadoriana Puplesis \& Diškus, 2002, A. amazonensis sp. nov. differs in the dark, glossy forewing with large, distinct, silvery shiny, subapical patches, and the dark fringe (golden cream in A. ecuadoriana); in the male genitalia, A. amazonensis sp. nov. differs in the valva with two large processes (only one, apical, in A. ecuadoriana), deeply caudally divided pseuduncus (undivided, widely rounded in A. ecuadoriana), greatly reduced gnathos, presence of two short lobes on posterior margin of vinculum (one lobe in A. ecuadoriana, see Fig. 26), presence of basal and median thickenings of valva (absent or different in A. ecuadoriana, see Fig. 26), and the apically wide phallus with large horn-like processes possessing very wide bases.

Male (Fig. 6). Forewing length about $2.3 \mathrm{~mm}$; wingspan about $5.2 \mathrm{~mm}$. Head: palpi metallic grey, very glossy; frontal tuft ochre-orange, dark brown-orange on frons; collar very indistinct, comprised of piliform scales; scape large, golden cream, distally with distinct shadow of blackish brown (however, visible at certain angle of view); antenna slightly longer than half the length of forewing; flagellum with 29 segments, blackish brown on upper side, pale grey with some purple iridescence on underside. Thorax and tegula shiny, blackish brown with some blue and purple iridescence. Forewing relatively wide but short; basal half of forewing dark grey, with strong blue and some purple iridescence; apical half with wide, oblique facia of black-brown scales (without purple iridescence), and with two large, almost merged patches of silvery shiny scales with little blue iridescence; fringe dark grey-brown; fringe-line comprised of black scales; underside of forewing blackish brown, without spots or androconia. Hindwing relatively wide, brown-grey on upper side and underside, without androconia; fringe brown-grey. Legs glossy, black-grey on upper side, dark brownish grey on underside; tarsi of hind legs brown-ochre to brownish cream distally.

Female. Unknown.

Male genitalia (Figs. 14, 27-35). Capsule significantly longer $(350 \mu \mathrm{m})$ than wide $(240 \mu \mathrm{m})$. Pseuduncus (Fig. 27) with two slender caudal processes. Uncus (Fig. 28) bilobed, wide, distally widened. Gnathos (Figs. 29, 32) greatly reduced, with slender arms; central plate absent. Valva (Figs. 30, 31) $180 \mu \mathrm{m}$ long, 50-75 $\mu \mathrm{m}$ wide, with two very large processes, and basal, and median thickenings; transtilla with transverse bar; sublateral proceeses straight (Fig. 35). Juxta absent. Vinculum very large, without distinct lateral lobes; posterior margin of vinculum with

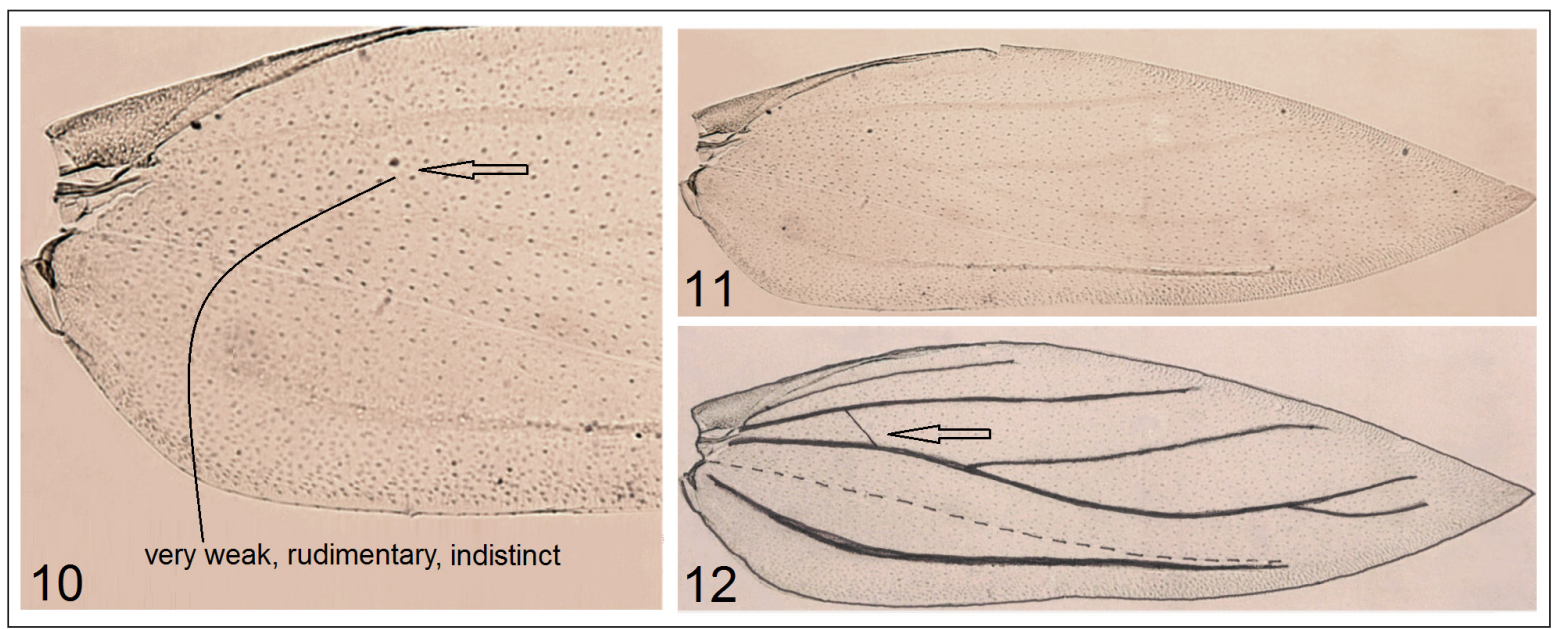

Figs. 10-12. Forewing venation of Acalyptris onorei Puplesis \& Diškus, paratype, slide no. AD324 (BMNH) 
two short lobes (Figs. 33, 34). Phallus (Fig. 14) $280 \mu \mathrm{m}$ long, greatly constricted in basal third (30-35 $\mu \mathrm{m}$ wide) but widened apical two thirds (100 $\mu \mathrm{m}$ wide); vesica with very distinct, rounded cathrema and three very large horn-like cornuti distally; bases of the cornuti very wide.

Bionomics (Figs. 2, 3, 7-9). Host plant: Psychotria L., Rubiaceae (identified by botanists Jaime Jaramillo A. and David Padilla Z., PUCE). Larvae mine in leaves in January, and, judging from observed numerous old (empty) leaf mines, possibly also in late December. Larva pale green, with dark green intestine and pale brown head; young larva bright green, there- fore, intestine invisible. Leaf mine (Figs. 8, 9) sinuous to very contorted, with dark green and black-green (sometimes brown-green) frass differently deposited at certain stages of the development (see Fig. 9); beginning of the gallery relatively wide. Exit slit on upper side of the leaf. Cocoon pale yellowish beige, matt (not glossy), rather round, $2 \mathrm{~mm}$ long, $1.5 \mathrm{~mm}$ wide. Adults fly in February.

Distribution (Fig. 1). This species occurs in the western Amazonian rainforest (Ecuador: Napo Province) at an elevation of about $400 \mathrm{~m}$.

Etymology. This species is named after Amazon where it occurs.

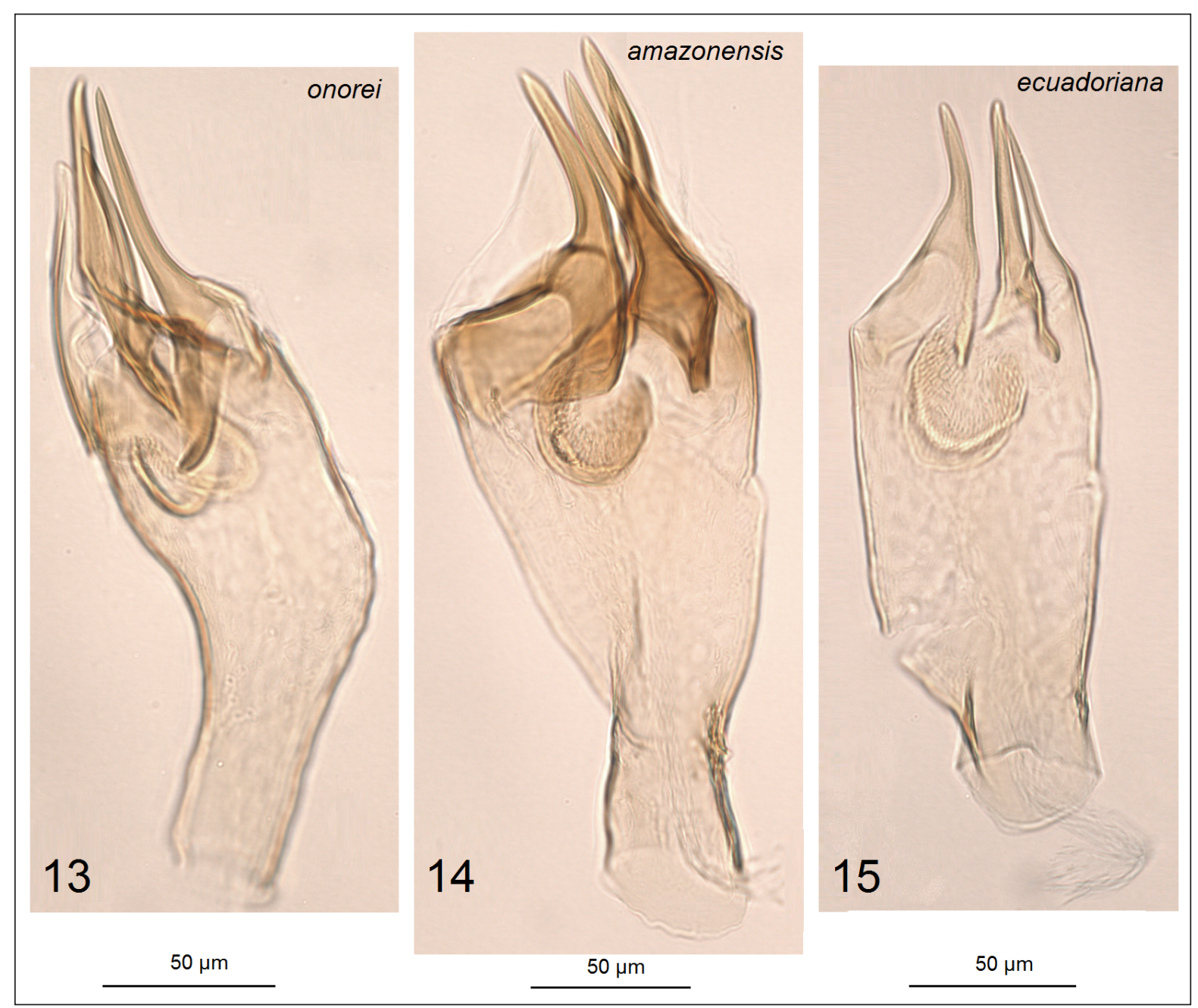

Figs. 13-15. Male genitalia of Acalyptris species occurring in the western Amazonian rainforest, phallus. 13 - A. onorei Puplesis \& Diškus, paratype, genitalia slide no. AD324; 14 - A. amazonensis Stonis \& Diškus, holotype, genitalia slide no. AD352; 15 - A. ecuadoriana Puplesis \& Diškus, paratype, genitalia slide no. AD325 (BMNH) 


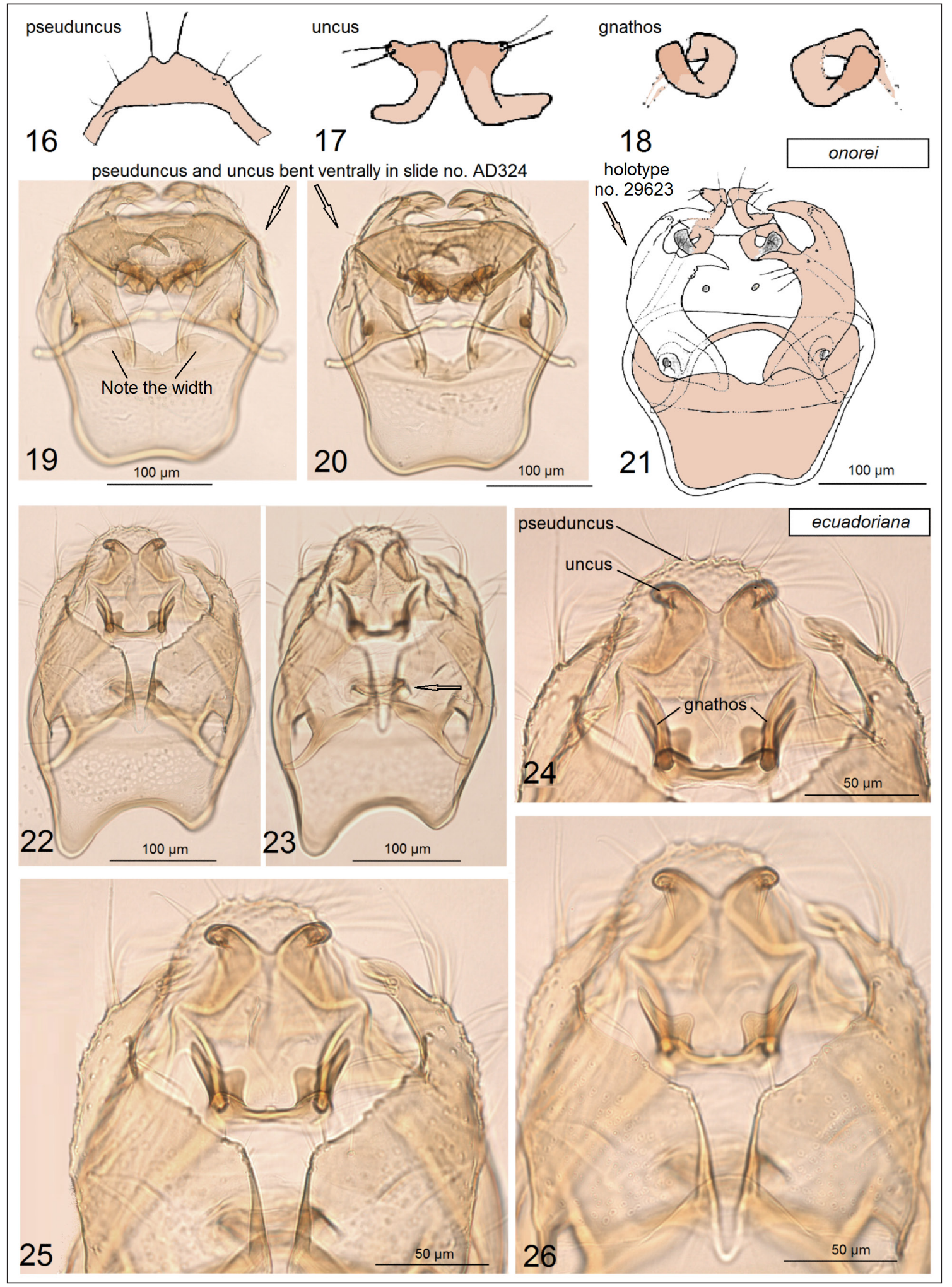

Figs. 16-26. Male genitalia of Acalyptris species occurring in the western Amazonian rainforest, capsule. 16 - A. onorei Puplesis \& Diškus, holotype, genitalia slide no. 29623, pseuduncus; 17 - same, uncus; 18 - same, gnathos; 19, 20 - same, paratype, genitalia slide no. AD324, capsule with phallus removed; 21 - same, holotype, genitalia slide no. 29623, capsule with phallus removed; 22-26 - A. ecuadoriana Puplesis \& Diškus, paratype, genitalia slide no. AD325, capsule with phallus removed (BMNH) 


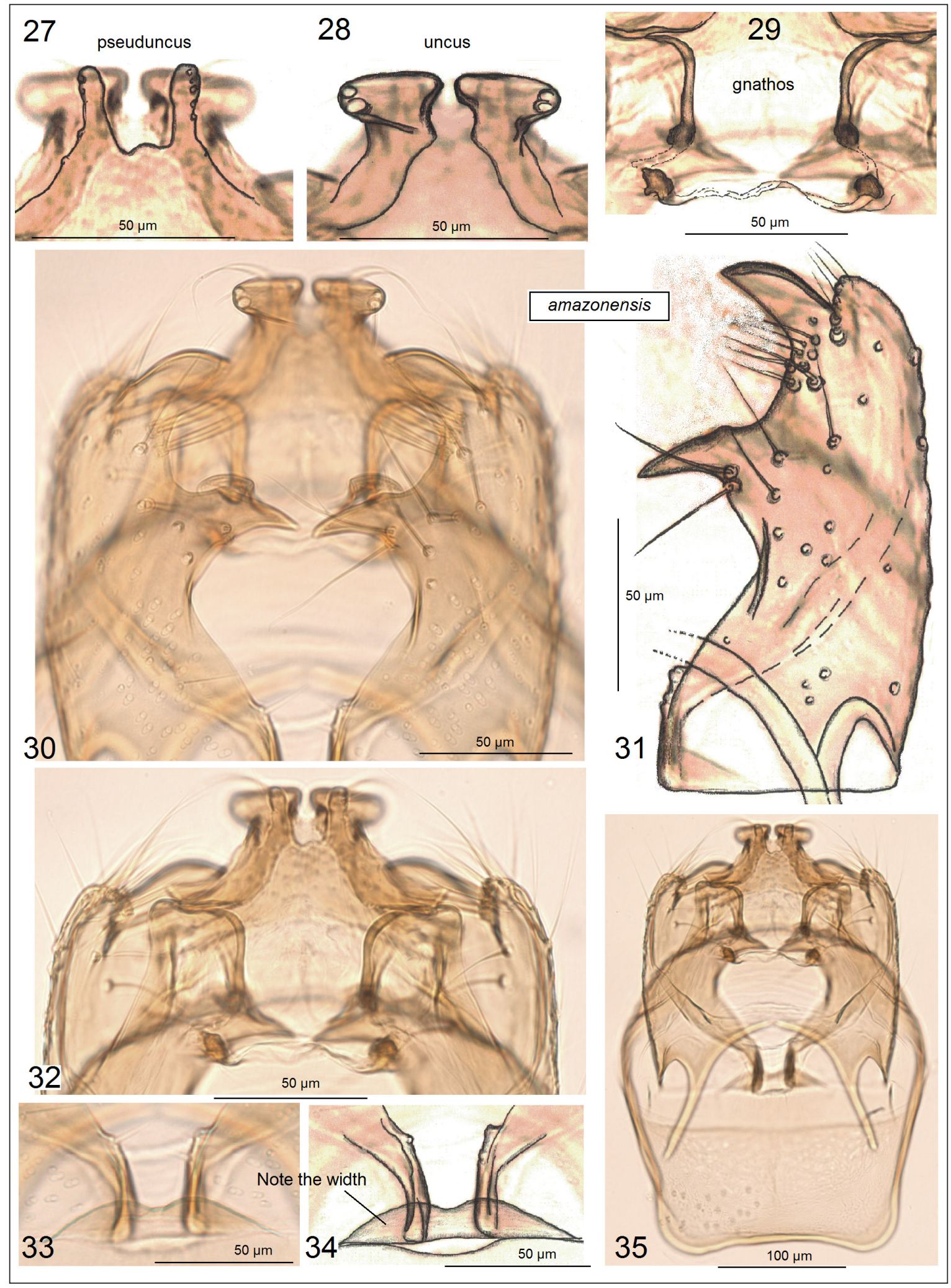

Figs. 27-35. Male genitalia of Acalyptris amazonensis Stonis \& Diškus, sp. nov., occurring in the western Amazonian rainforest, holotype, capsule with phallus removed, genitalia slide no. AD352 (BMNH). 27 - pseuduncus; 28 - uncus; 29 - gnathos; 30,31 - valvae; 32 - gnathos and pseuduncus; 33 , 34 - posterior margin of vinculum with lobes; 35 - general view of capsule with phallus removed 


\section{DISCUSSION}

The genus Acalyptris Meyrick was reported as a very prolific, diverse and even dominant Nepticulidae genus in the tropical lowlands of America (Puplesis, Robinson, 2002b). That was also confirmed by our recent studies (e.g., Stonis et al., 2013, 2017b; Stonis, Remeikis, 2015).

Neotropical Acalyptris exhibit a remarkable range of morphological structure. The A. latipennata group was originally designated by Puplesis et al. (2002b), and later it was listed in the Catalogue of the world fauna (Diškus, Puplesis, 2003) and included four species: A. latipennata (Puplesis \& Robinson, 2000); A. dividua Puplesis \& Robinson, 2000; A. onorei Puplesis \& Diškus, 2002; and A. ecuadoriana Puplesis \& Diškus, 2002. The group was recognized as highly distinct and endemic to the Neotropics. But until now, biology of the group has been totally unknown.

Recently one more species, A. paradividua Šimkevičiūtè \& Stonis, from southern Mexico has been added (Šimkevičiūtè et al., 2009), and one species, A. amazonensis, from Ecuador is described in the current paper. The latter description not only brought the first record of the host plant (Psychotria sp., Rubiaceae) but also allowed us to refine the diagnostic characters of the group. Here we postulate that the A. latipennata group can be characterized at least by the characters listed below.

1. Forewing wide (usually slender in other Acalytris).

2. Scaling of the forewing often yellowish cream, always with a distinct oblique, dark, postmedian or subapical, fascia-like marking (some other Acalyptris also possess an oblique postmedian marking, however, it is not so persistent as in the latipennata group).

3. Phallus always with three very large, hornlike cornuti apically (a unique, supposedly, apomorphic character, not found in other Acalyptris).

4. Carinae of the phallus always absent (carinae always present in other Acalyptris, probably even including A. lascuavella Puplesis \& Robinson which possesses short, rounded carinae).
5. Tube of the phalus often constricted at basal part (particularly characteristic of the A. onorei species "complex" but not characteristic of the genus in general; the constricted phallus seems to be an apomorphy of the A. latipennata group, or at least of the onorei species "complex").

6. Uncus distinctly paired and strongly developed in the A. onorei species "complex" (it seems to be apomorphy; uncus never paired in the remaing Neotropical Acalyptris but represents a distinctive, unpaired structure in the shape of inverted V or Y).

7. Gnathos paired, often partially reduced (except for a single species, $A$. latipennata which posseses an unpaired gnathos with one large caudal process; very most of the remaining $\mathrm{Ne}$ otropical Acalyptris possess a stout gnathos with one caudal process).

8. Valva with a large inner (median) process, except for A. ecuadoriana (only a few other $\mathrm{Ne}$ otropical Acalyptris have a valva with an inner process; and it seems that, if available, it is not homologous to the process in the A. latipennta group).

9. Sublateral processes of valva long or very long (some other Neotropical Acalyptris also possess rather long sublateral processess).

10. Transtilla always with a transverse bar (only some other Neotropical Acalyptris possess a transverse bar; in general, for Acalyptris the absence but not a presence of the transverse bar is more characteristic).

11. Vinculum large or very large, except for A. ecuadoriana which possesses a moderately large vinculum.

12. Posterior margin of vinculum usually with either two short, rounded lobes, or one short, rounded lobe.

13. Lateral apodemes, which are so characteristic of the male genital capsule of the most Acalyptris, fully absent in the A. latipennata group.

Due to the listed characters, the group seems rather outstanding within Acalyptris. The placement in Acalyptris was subtly doubted by van Nieukerken et al. (2016); indeed, it is possible that the group may belong to a still unknown 
and undescribed taxon related to Acalyptris and (or) Fomoria Beirne. It is interesting that $A$. latipennata, which gave name to the group, was originally described as a Fomoria Beirne species (Puplesis, Robinson, 2000), only later it was transferred to Acalyptris (Puplesis et al., 2002b). However, the forewing venation (see Figs. 1012 ) is rather very close to the most of Acalyptris, and totally identical with the Belizean A. bovicorneus (see illustrated in Puplesis, Robinson, 2000: Fig. 65), which is a rather typical Acalyptris. A closed cell in A. bovicorneus is formed by the same weak, indistict, and possibly rudimentary vein $\mathrm{Rs}+\mathrm{M}$.

So far, no females for the species of A. latipennata group are known; host-plant associations were also studied for a single A. amazonensis. Therefore more studies are urgently needed, preferably in Central America or the western part of the Amazon Basin, to clarify the placement or the taxonomic status of the remarkable A. latipennata group.

\section{ACKNOWLEDGEMENTS}

We are extremely grateful to Professor Dr. Giovanni Onore, a former professor at the Pontifical Catholic University of Ecuador, Quito, Ecuador, for all necessary preparations for a study permit to collect material in Ecuador and for his generous scientific collaboration. We are also indebted to Ole Karsholt, the late Professor Niels P. Kristensen (ZMUC), and the late Dr. Gaden S. Robinson (BMNH) for the initial stimulus to start the Neotropical project as well as for generous support during its course and the loan of the Neotropical material. For identification of various host plants from Ecuador, including the host plant of Acalyptris amazonensis, we thank botanists Jaime Jaramillo A. and David Padilla Z. (PUCE).

This study was partially supported by the Research Foundation of the Lithuanian University of Educational Sciences (2018).

Received 3 May 2018 Accepted 27 September 2018

\section{References}

1. Diškus A, Puplesis R. Catalogue of the world Nepticuloidea \& Tischerioidea. In: Puplesis R, Diškus A, editors. The Nepticuloidea \& Tischerioidea (Lepidoptera) - a global review, with strategic regional revisions. Kaunas: Lutute Publishers; 2003. p. 318-436.

2. Johansson R, Nielsen ES, Nieukerken van EJ, Gustafsson B. The Nepticulidae and Opostegidae (Lepidoptera) of North West Europe. Fauna Entomol Scand. 1990; 23(1/2): 1-739.

3. Nieukerken van EJ, Doorenweerd C, Hoare JR, Davis DR. Revised classification and catalogue of global Nepticulidae and Opostegidae (Lepidoptera, Nepticuloidea). ZooKeys. 2016; 628: 65-246.

4. Puplesis R. The Nepticulidae of Eastern Europe and Asia: western, central and eastern parts. Leiden: Backhuys Publishers; 1994. 552 p.

5. Puplesis R, Diškus A. The Nepticuloidea \& Tischerioidea (Lepidoptera) - a global review, with strategic regional revisions. Kaunas: Lututè Publishers; 2003. 512 p.

6. Puplesis R, Robinson GS. A review of the Central and South American Nepticulidae (Lepidoptera) with special reference to Belize. Bull Nat Hist Mus Entomol. 2000; 69(1): 3-114.

7. Puplesis R, Diškus A, Robinson GS. New Neotropical Nepticulidae (Lepidoptera) from the western Amazonian rainforest and the Andes of Ecuador. Bull Nat Hist Mus Entomol. 2002a; 71(1): 19-58.

8. Puplesis R, Diškus A, Robinson GS, Onore G. A review and checklist of the Neotropical Nepticulidae (Lepidoptera). Bull Nat Hist Mus Entomol. 2002b; 71(1): 59-76. http://dx.doi. org/10.1017/S0968045402000032

9. Remeikis A, Stonis JR, Diškus A, Davis DR. The first photographic documentation and new data on Enteucha guajavae (Lepidoptera, Nepticulidae), a pest of guava from equatorial America. In: Stonis JR, Hill SR, Diškus A, Auškalnis $\mathrm{T}$, editors. Selected abstracts and 
papers of the First Baltic International Conference on Field Entomology and Faunistics. Vilnius: Edukologija Publishers; 2014. p. 65-74.

10. Stonis JR, Diškus A, Katinas L, Solis MA. Asteraceae: host to the greatest diversity of leaf-mining Nepticulidae (Lepidoptera) in South America? Proc Entomol Soc Wash. 2018; 4(in press).

11. Stonis JR, Diškus A, Remeikis A. The first description of the leaf-mining Nepticulidae (Lepidoptera) feeding on the South American plant genus Liabum, Asteraceae. Zootaxa. 2015; 4040(5): 576-82.

12. Stonis JR, Diškus A, Remeikis A, Cumbicus Torres N. Rosaceae-feeding Nepticulidae (Lepidoptera) of South America: some taxonomic and trophic diversity revealed. Biologija. 2016a; 62(4): 215-32.

13. Stonis JR, Diškus A, Remeikis A, Davis DR, Solis MA, Cumbicus Torres N. The first record of Baccharis L. (Asteraceae) as a host-plant genus for Nepticulidae (Lepidoptera), with description of new Stigmella species from South America. Zootaxa. 2016b; 4136(1): 101-28. http://doi.org/10.11646/zootaxa.4136.1.4

14. Stonis JR, Diškus A, Remeikis A, Solis MA. The American Brachinepticula gen. nov. and Manoneura Davis (Nepticulidae): a new generic concept based on a reinforced cathrema in the phallus. Biologija. 2018; 64(2): 99-128.

15. Stonis JR, Diškus A, Remeikis A, Gerulaitis V, Karsholt O. Leaf-mining Nepticulidae (Lepidoptera) from record high altitudes: documenting an entire new fauna in the Andean páramo and puna. Monograph. Zootaxa. 2016c; 4181(1): 1-94. doi:http://doi. org/10.11646/zootaxa.4181.1.1

16. Stonis JR, Diškus A, Remeikis A, Karsholt O, Cumbicus Torres N. Illustrated review of the leaf-mining Nepticulidae of the central Andes (Peru and Bolivia). Monograph. Zootaxa. 2017b; 4257(1): 1-70. https://doi. org/10.11646/zootaxa.4257.1.1

17. Stonis JR, Diškus A, Remeikis A, Monro A. The mystery of the tiny Urticaceae-feeders: documentation of the first leaf-mining Nepticulidae (Lepidoptera) species from equatorial America associated with Phenax, Boehmeria and Pilea. Biologija. 2017c; 63(2): 105-25.

18. Stonis JR, Diškus A, Remeikis A, Navickaitè A. Study methods of Nepticulidae: micro-mounts of genitalia structures. In: Stonis JR, Hill SR, Diškus A, Auškalnis T, editors. Selected abstracts and papers of the First Baltic International Conference on Field Entomology and Faunistics. Vilnius: Edukologija Publishers; 2014. p. 32-5.

19. Stonis JR, Diškus A, Remeikis A, Noreika R, Schuster J. Four new leaf-mining Acalyptris species from Guatemala and Belize, with new data on bionomics of Stigmella pruinosa (Lepidoptera: Nepticulidae). Zootaxa. 2013; 3737(2): 101-17.

20. Stonis JR, Diškus A, Remeikis A, Karsholt O. Do leaf-mining Nepticulidae occur in the natural but so threatened Andean Polylepis forests? Biologija. 2016d; 62(2): 83-97. http:// dx.doi.org/10.6001/biologija.v62i2.3334

21. Stonis JR, Remeikis A. The first records on the genus Acalyptris from the Caribbean (Lepidoptera: Nepticulidae). Zootaxa. 2015; 4057(1): 79-90.

22. Stonis JR, Remeikis A, Diškus A, Forero D, Cumbicus Torres N. A report on Lamiaceae-feeding Nepticulidae (Lepidoptera) from South America. Zootaxa. 2017a; 4338(1): 128140. https://doi.org/10.11646/zootaxa.4338.1.6

23. Stonis JR, Remeikis A, Diškus A, Megoran N. New species of leaf-mining Nepticulidae (Lepidoptera) from the Neotropical and AndoPatagonian regions, with new data on hostplants. Zootaxa. 2017d; 4272(1): 1-39. https:// doi.org/10.11646/zootaxa.4272.1.1

24. Šimkevičiūtè A, Stonis JR, Diškus A. Taxonomic checklist of Nepticulidae of Mexico, with the description of three new species the from Pacific Coast (Insecta, Lepidoptera). Acta Zool Lituan. 2009; 19(4): 268-77. 
Jonas Rimantas Stonis, Arūnas Diškus

\section{NAUJOS RŪŠIES, PRIKLAUSANČIOS SAVITAI \\ IR IKI ŠIOL DISKUTUOTINAI ACALYPTRIS \\ LATIPENNATA GRUPEI, APRAŠYMAS \\ (LEPIDOPTERA, NEPTICULIDAE)}

Santrauka

Straipsnyje aprašoma nauja mokslui Acalyptris amazonensis rūšis, aptikta vakarinès Amazonijos miškuose, Ekvadore, priklausanti išskirtinei, tačiau iki šiol diskutuotinai A. latipennata rūšiu grupei. Pirmą kartą fotografijomis dokumentuojamos ir kitos dvi Ekvadore aptinkamos rūšys: A. onorei Puplesis ir Diškus bei A. ecuadoriana Puplesis ir Diškus, aprašytos 2002 metais. Straipsnyje pateikiama išsami A. amazonensis minų morfologijos dokumentacija. Nustatyti nauji A. latipennata rūšių grupès požymiai leidžia ne tik geriau ją identifikuoti, bet ir galbūt liudija A. latipennata rūšių grupès monofiletinę kilmę.

Raktažodžiai: Acalyptrisamazonensis, Acalyptris Meyrick, lapų minos, nauja rūšis, Nepticulidae, latipennata grupè 